\title{
CARACTERIZATION OF AUJESZKY'S DISEASE VIRUS ISOLATED FROM SOUTH BRAZIL IN THE LAST TWENTY YEARS BY RESTRICTION ENZYME ANALYSIS
}

\author{
Rejane Schaefer ${ }^{1 *}$; Janice Ciacci Zanella ${ }^{1}$; Nelson Mores ${ }^{1}$; Kleitton Adolfo Pan²; Régia Maria Feltrim Dambros ${ }^{3}$; \\ Marisete Fracasso Schiochet ${ }^{1}$; Michele Coldebella ${ }^{4}$
}

${ }^{1}$ Embrapa Suínos e Aves, Concórdia, Santa Catarina, Brasil; ${ }^{2}$ Faculdade de Veterinária, Universidade Federal de Santa Maria, Santa Maria, Rio Grande do Sul, Brasil; ${ }^{3}$ Cedisa, Concórdia, Santa Catarina, Brasil; ${ }^{4}$ Universidade do Contestado, Concórdia, Santa Catarina, Brasil

Submitted: November 06, 2005; Returned to authors for corrections: March 08, 2006; Approved: May 08, 2006

\begin{abstract}
Aujeszky's disease virus (ADV) belongs to Herpesviridae family and is an important etiological agent which infects pigs causing economic losses in swine producing countries worldwide and international trade restrictions to products of swine origin. An eradication program for ADV was established in Santa Catarina State since 2001. The last outbreak was reported in July 2004 and since then none has been reported. The disease has been controlled with the use of a genetic modified vaccine and elimination of seropositives. Aiming the characterization of ADV isolated in the South of Brazil in the last twenty years (1983-2003), a retrospective study based on the genomic analysis of the isolates through a digestion of viral genomic DNA with restriction enzyme Bam HI was done. Thirty-seven ADV samples isolated from swine from the States of Santa Catarina, Parana and Rio Grande do Sul were analyzed. These isolates were compared to the reference strains NIA-4, Bartha and Begonia. The most predominant genomic arrangement was type II found in 33 samples isolated in Santa Catarina State and in one isolate from Rio Grande do Sul State. Genomic arrangement type I, characteristic of vaccine strains was identified in 2 isolates from Parana State and in 1 isolate from Rio Grande do Sul State.
\end{abstract}

Key words: Aujeszky's disease virus, swine, restriction endonuclease analysis

\section{INTRODUCTION}

Aujeszky's Disease (AD) or Pseudorabies (PRV) is a viral infection of pigs caused by a Suid Herpesvirus-1, a member of Herpesviridae Family, Alphaherspesvirinae Sub-family. The disease is considered an important cause of economic losses in pig husbandry worldwide due to respiratory distress, nervous and genital disorders and mortality, according to the age of the host and the virulence of the virus strain involved (9). Moreover, the presence of the infection in swine herds causes international trade restrictions to products of swine origin.

The pig is the only natural host of PRV in which, after a primary infection, a latent infection is established in sensory ganglia of the central nervous system and lymphoid tissue of the tonsils (18). Reactivation of latent infections can occur at any time of stress (3). Latently infected pigs are considered the source of infection for a diverge range of secondary hosts, which include horse, cattle, sheep, goats, dogs and cats, and many feral species. In these species, the infection is frequently fatal (6). PRV consists of an enveloped nucleocapsid that surrounds a linear genome of about $145 \mathrm{~kb}$ of DNA which codifies for about 100 proteins. Only one serotype of PRV is recognized, but differences between some strains can be demonstrated by panels of monoclonal antibodies. PRV strains can also be differentiated by biological and physical markers. Genomic differences, as revealed by restriction endonuclease analysis (REA), can also be used to differentiate PRV strains, producing useful information in epidemiological studies (9).

*Corresponding Author. Mailing address: Embrapa Suínos e Aves, BR 153, Km 110, Vila Tamanduá, Caixa Postal 21. 89700-000, Concórdia, SC, Brasil. Tel.(+5549) 3441-0423, Fax: (+5549) 3442-8559. E-mail: rejane@cnpsa.embrapa.br 
In order to reduce economic losses in pig production, many countries have implanted eradication programs based on the use of a genetic modified vaccine (17). In the State of Santa Catarina, Brazil, the infection of pigs with PRV was considered endemic until the establishment, in 2001, of a program to control and eradicate Aujeszky's disease organized by Embrapa Swine and Poultry (13). The program measures include two protocols, total depopulation of herds with AD outbreaks or with seroprevalence higher than $10 \%$ and differencial serology of breeding pigs and elimination of seropositives. These measures proved to be very efficient and since July, 2004 no cases of AD have been notified (12). However, Aujeszky's disease in the border states of Rio Grande do Sul and Parana States is considered sporadic, being the last diagnostic and elimination of the disease reported in 2003, with no further cases since then (4).

Aiming to deepen the study of characterization of PRV strains isolated in Santa Catarina State in twenty years (19832003), comparing these strains with others isolated in Rio Grande do Sul and Parana State and with PRV reference strains, this article describe the characterization of PRV strains based on the genome analysis of isolates according to restriction patterns showed after the digestion of genomic viral DNA with restriction enzyme Bam HI.

\section{MATERIALS AND METHODS}

\section{Viruses and cells}

Thirty-seven PRV strains isolated from 1983 to 2003 in South Brazil by Embrapa Swine and Poultry (CNPSA) and by Animal Health Diagnostic Center (CEDISA) were studied (Table 1). Most samples were isolated from brain and lungs of pigs. One sample was isolated from a brain of a dog. Sample EVI 011/03 was isolated during an outbreak of AD in the North of Rio Grande do Sul State, in 2003 (4). The strains NIA-4 (1), Bartha (10) and Begonia (Intervet International B.V. Holland) were used as reference viruses for REA. All viruses were cultured in swine kidney cells (SK6) grown in F10-199 medium (Ham F10 + Earle's 199; Cultilab) or in swine testis cells (ST) grown in RPMI-1640. The medium was supplemented with gentamicin $(10 \mathrm{mg} / \mathrm{mL})$, fungizon $(1 \mathrm{mg} /$ $\mathrm{mL}$ ) and $5 \%$ fetal calf serum.

\section{Genomic DNA extraction}

Confluent SK6 or ST cells were infected with field strains of PRV at a multiplicity of infection of $0.1-1$. When cytopatic effect reached $90-100 \%(30 \mathrm{~h})$, the culture medium was clarified (5.000 $\mathrm{x}$ g for 20 minutes) and the supernatant centrifuged on a sucrose cushion $25 \%$ at $100.000 \mathrm{x}$ g for 2 hours at $4^{\circ} \mathrm{C}$. The viral pellet was re-suspended in TEN (Tris-Cl $10 \mathrm{mM}$, pH 7.4; $\mathrm{NaCl}$, $150 \mathrm{mM}$; EDTA $1 \mathrm{mM}, \mathrm{pH} 8.0$ ) and treated with $1 \%$ sodium dodecyl sulfate (SDS) and $100 \mu \mathrm{g} / \mu \mathrm{L}$ proteinase $\mathrm{K}$ for $1 \mathrm{~h}$ at $37^{\circ} \mathrm{C}$. After digestion, the viral DNA was extracted once with phenol, precipitated with cold ethanol, re-suspended in TE $\mathrm{pH}$ 8.0 and maintained at $4^{\circ} \mathrm{C}(16)$.

\section{Restriction endonuclease analysis (REA)}

Viral DNA was digested with restriction enzyme Bam HI under the conditions recommended by the manufacturer (New England Biolabs). Digested DNA were subjected to electrophoresis at $10 \mathrm{~V}$ for 20 hours on a $0.6 \%$ agarose gel in Tris-Borate-EDTA ( $45 \mathrm{mM}$ Tris, $45 \mathrm{mM}$ borate and $1 \mathrm{mM}$ EDTA). The gels were stained with ethidium bromide $(5 \mathrm{ug} / \mathrm{mL})$ and photographed under UV light. Genomic typing of PRV isolates was performed according to Herrmann et al. (8).

\section{RESULTS AND DISCUSSION}

Thirty-seven PRV strains isolated in the South of Brazil during a period of 20 years (1983-2003) were analyzed through a digestion of viral DNA with restriction enzyme (Table 1). According to Herrmann (8), four genomic arrangement are described based on migration patterns of the three major fragments appeared after digestion of viral genomic DNA with Bam HI. The group I viruses are similar to or identical to the published Bam HI DNA pattern (15). The group II strains lack one fragment (No. 2) of group I but possess two new fragments (above and below fragment 4). The genomic type III lacks a restriction site between the fragments 2 and $9(7)$, with the appearance of a fragment (2+9) just below the fragment 1 (Fig. 1). According to the criteria established by Herrmann (8), most isolates showed a genomic arrangement type II (34 isolates) and three isolates showed a genomic arrangement type I (Table 1). Genomic type III was not observed. Moreover, intermediates of the two genome types do exist (Ii and IIi, respectively). Variations of group I have an additional fragment below fragment 4 , and variations of group II have only one new fragment above fragment 4 (Fig. 2). Following this new subdivision, the isolates could be separated in genomic arrangement type I ( 1 isolate), Ii ( 2 isolates), II (18 isolates) e IIi (16 isolates). The occurrence of intermediary genomes could be explained by the existence of successive re-infections, which

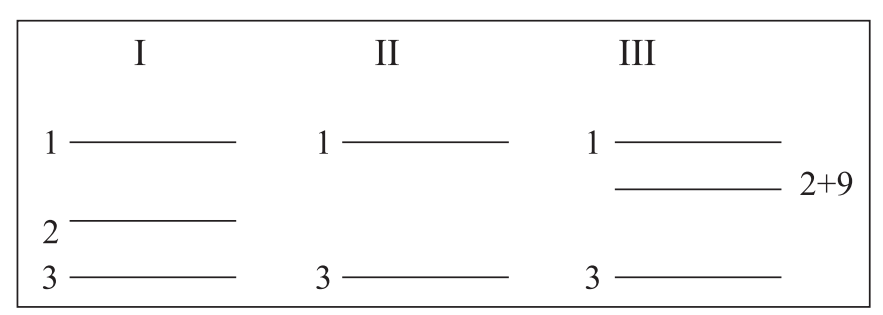

Figure 1. Schematic presentation of PRV genomic types (I, II e II) based on the migration of the first three fragments obtained after digestion of viral genomic DNA with restriction enzyme Bam HI (2). 
Table 1. Origin and description of PRV virus strains

\begin{tabular}{|c|c|c|c|c|}
\hline Sample No. & Species & Year of isolation & Origin & Genomic type \\
\hline Begônia $^{a}$ & $\mathrm{NI}$ & NI & Intervet International B.V, Holanda & I \\
\hline $438 / 84$ & Swine & 1984 & Toledo, Parana & $\mathrm{Ii}^{*}$ \\
\hline $536 / 84$ & Swine & 1984 & Toledo, Parana & Ii \\
\hline $137 / 89$ & Swine & 1989 & Erechim, Rio Grande do Sul & I \\
\hline $607 / 83$ & Swine & 1983 & Faxinal dos Guedes, Santa Catarina & II \\
\hline $659 / 83$ & Swine & 1983 & Faxinal dos Guedes, Santa Catarina & II \\
\hline $843 / 83$ & Swine & 1983 & Faxinal dos Guedes, Santa Catarina & II \\
\hline $879 / 84$ & Swine & 1984 & Ipumirim, Santa Catarina & II \\
\hline $266 / 86$ & Swine & 1986 & Xanxerê, Santa Catarina & II \\
\hline $347 / 89$ & Swine & 1989 & Rio do Sul, Santa Catarina & II \\
\hline $1479 / 01$ & Swine & 2001 & Xanxerê, Santa Catarina & II \\
\hline $1717 / 02$ & Swine & 2002 & Concórdia, Santa Catarina & II \\
\hline $1718 / 02$ & Swine & 2002 & Concórdia, Santa Catarina & II \\
\hline $1468 / 02$ & Swine & 2002 & Itapiranga, Santa Catarina & II \\
\hline $008 / 02$ & Swine & 2002 & Pres. Castelo Branco, Santa Catarina & II \\
\hline $1817 / 03$ & Swine & 2003 & Rio do Sul, Santa Catarina & II \\
\hline EVI011/03 & Swine & 2003 & Pinheirinho do Vale, Rio Grande do Sul & II \\
\hline $227 / 83$ & Swine & 1983 & Ipumirim, Santa Catarina & IIi \\
\hline $447 / 83$ & Canine & 1983 & Seara, Santa Catarina & Illi \\
\hline $1455 / 01$ & Swine & 2001 & Concórdia, Santa Catarina & IIi \\
\hline $1702 / 02$ & Swine & 2002 & Seara, Santa Catarina & Illi \\
\hline $1265 / 02$ & Swine & 2002 & Pres. Castelo Branco, Santa Catarina & IIi \\
\hline $1266 / 02$ & Swine & 2002 & Pres. Castelo Branco, Santa Catarina & Illi \\
\hline $1336 / 02$ & Swine & 2002 & Seara, Santa Catarina & IIi \\
\hline 1951/02 & Swine & 2002 & Pres. Castelo Branco, Santa Catarina & IIi \\
\hline $1867 / 02$ & Swine & 2002 & Braço do Norte, Santa Catarina & IIi \\
\hline
\end{tabular}

${ }^{a}$ Reference strains; *i: intermediary; NI: Not informed

can promote viral recombination (8). Differently of what was found by Herrmann (8), there was no relationship between the isolation year and distribution of the genome types. For comparison, it was included, as reference strains, the Northern Ireland Aujeszky-4 (NIA-4), Bartha and Begonia strains (the last one is the vaccine strain used in the $\mathrm{AD}$ eradication program in course in Santa Catarina State). All the vaccine strains could be grouped as type I, but they were significantly different in their DNA pattern because they lack the fragment $\mathrm{Bam} \mathrm{HI} / 7$, which corresponds to a part of US region of PRV genome (11). 


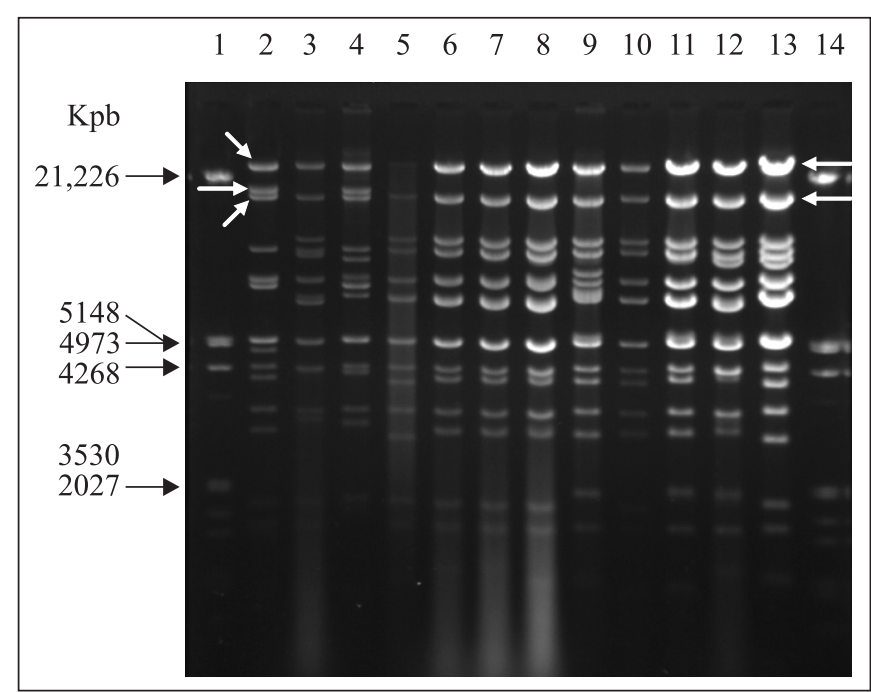

Figure 2. Restriction profiles of PRV isolates after digestion of viral genomic DNA with Bam HI. L1 and L14: molecular ladder HindIII/EcoRI, L2: Begonia, L3: 1479/01, L4: 438/84, L5: 1108/88, L6: 1265/02,L7: 1266/02,L8: 1951/02,L9: 1867/02,L10:447/83,L11: 467/83, L12: 879/84, L13: 347/89. Black arrows: Fragments size of DNA digest. White arrows: fragments considered for typing.

PRV isolates representative of genomic arrangement type I are found in the United States and Central Europe, while isolates showing the genomic arrangement type II are predominantly found in Central Europe and Japan. The groups III (genome type III) and IV (genome type IV) are strictly limited to isolates originating from Northern Europe and Thailand, respectively (8).

In Brazil, previous work has identified genomic arrangement type II as the most predominant in 28 out of 30 PRV isolates analysed (14). In that work, all 19 PRV isolates from Santa Catarina State showed a genomic arrangement type II. Similarly, in this study, all 33 PRV isolates from Santa Catarina State showed a genomic arrangement type II. An unexpected finding was the identification of an sample stored in our laboratory, which was isolated from pigs in 1989, from a commercial herd located in Erechim, Rio Grande do Sul. According to D'Ávila da Silva (4), excepting the AD outbreak occurred in Rio Grande do Sul State in 2003, outbreaks of AD haven't been described since 1954. Moreover, the virus isolated in 1989 showed a genomic type never found before in that State (genomic arrangement type I), once PRV isolates from the recent outbreak (2003) showed a genomic arrangement type II. In Brazil, PRV isolates showing a genomic arrangement type I had only been identified in pigs, from São Paulo State, in 1986 and 1990 (14). In our work, two other samples isolated in Toledo, Paraná State in 1984 were characterized as genomic arrangement type Ii.

In South America, PRV isolates showing a genomic arrangement type I were identified by Echeverria (5) in Argentina, where $\mathrm{AD}$ is considered endemic. In this manner, considering that the main source of infection for PRV is the latently infected pig, we suppose that there is a possibility that PRV isolates with a genomic arrangement type I have been introduced in Rio Grande do Sul State by importation of latently infected pigs, or through the transit of latently infected wild pigs.

In conclusion, REA, in the classification of PRV, are useful to epidemiological investigations producing helpful information to the identification of the source of infection in a given outbreak. It allowed us to find a genomic type in Rio Grande do Sul State which was never identified. However, according to Kluge (9), although it is possible to say with a high degree of certainty that virus strains are different, it is not possible to say with the same certainty that virus strains with genomic similarities and identical biological markers are unique and the same. It indicates that more investigation has to be done in order to differentiate such virus strains.

\section{RESUMO}

\section{Caracterização de amostras do vírus de Aujeszky isoladas na região Sul do Brasil nos últimos vinte anos através de análise de restrição enzimática}

O vírus da doença de Aujeszky (VDA) pertencente à família Herpesviridae é um importante agente etiológico que infecta suínos causando perdas na produção de suínos no mundo inteiro e restrições para o comércio internacional de suínos ou de seus subprodutos. No estado de Santa Catarina, Brasil, foi instituído em 2001 um programa de erradicação da doença de Aujeszky (DA). O último surto da DA foi reportado em julho de 2004 e desde então não foram notificados mais casos. A doença tem sido controlada com o uso de uma vacina geneticamente modificada e eliminação de animais soropositivos para o VDA. Visando caracterizar amostras do VDA isoladas nos últimos vinte anos (1983-2003) na região Sul do Brasil, foi realizado um estudo retrospectivo baseado na análise do genoma dos vírus isolados de acordo com os perfís de restrição apresentados após a digestão do DNA genômico viral com a enzima Bam HI. Foram analisadas trinta e sete amostras isoladas de suínos oriundos dos estados de Santa Catarina, Paraná e Rio Grande do Sul. Os isolados foram comparados com as amostras de referência NIA-4, Bartha e Begônia. O arranjo genômico predominante, encontrado em 33 amostras isoladas em Santa Catarina e em uma isolada no Rio Grande do Sul, foi o do tipo II. O arranjo genômico do tipo I, característico de amostras de vírus vacinal foi identificado em duas amostras isoladas no Paraná e em uma amostra isolada no Rio Grande do Sul.

Palavras-chave: vírus da doença de Aujeszky, suínos, análise com endonuclease de restrição 


\section{REFERENCES}

1. Baskerville, A.; Mcferran, J.B.; Dow, C. Aujeszky's disease in pigs. Vet. Bull., 43, 465-480, 1973.

2. Christensen, L.S. The population biology of suid herpesvirus 1 . APMIS, S. 47, 103, 5-48, 1995.

3. Davies, E.B.; Beran, G.W. Spontaneous shedding of pseudorabies virus from a clinically recovered post parturient sow. J. Am. Vet. Med. Assoc., 176, 1345-1347, 1980.

4. D'ávila, A.S.; Sortica, V.A.; Braga, A.C.; Spilki, F.R.; Franco, A.C.; Esteves, P.A.; Rijsewijk, F.A.M.; Rosa, J.C.A.; Carvalho, H.B.C.R.; Oliveira, A.P.; Roehe, P.M. Caracterização antigênica e molecular de oito amostras do vírus da doença de Aujeszky isoladas no Estado do Rio Grande do Sul em 2003. Pesq. Vet. Bras., 25, 21-24, 2005.

5. Echeverria, M.G.; Norimine, J.; Galosi, C.M.; Oliva, G.A.; Etcheverrigaray, M.E.; Nosetto, E.O.; Tohya, Y.; Mikami, T. The genotype of Aujeszky's disease viruses isolated in Argentina. J. Vet. Med. Sci., 56, 985-987, 1994.

6. Fenner, F.J.; Gibbs, E.P.J.; Murphy, F.A.; Rott, R.; Studdert, M.J.; White, D.O. Herpesviridae. In: Veterinary Virology, 2nd ed. Academic Press, California, 1987, p.337-368.

7. Gielkens, A.L.J.; van Oirschot, J.T.; Berns, A.J.M. Genome differences among field isolates and vaccine strains of pseudorabies virus. $J$. Gen. Virol., 66, 69-82, 1985.

8. Herrmann, S.C.; Heppner, B.; Ludwig, H. Pseudorabies viruses from clinical outbreaks and latent infections grouped into four major genome types. Curr. Top. Vet. Med. Anim. Sci., 27, 378-401, 1984.

9. Kluge, J.P.; Beran, G.W.; Hill, H.T.; Platt, K.B. Pseudorabies (Aujeszk's disease). In: Straw, B.E.; D'allaire, S.; Mengeling, W.L.; Taylor, D.J. (eds). Diseases of swine, $8^{\text {th }}$ edition, Iowa State University Press, Ames, Iowa - USA, 1999, p.147-160.

10. Lomniczi, B.; Watanabe, S.; Bem-Porat, T.; Kaplan, A.S. Genome location and identification of functions defective in the Bartha vaccine strain of pseudorabies virus. J. Virol., 61, 796-801, 1987.

11. Mettenleiter, T.C.; Lukacs, N.; Rziha, H.J. Pseudorabies virus avirulent strains fail to express a major glycoprotein. J. Virol., 56, 307-311, 1985

12. Morés, N.; Amaral, A.L.; Ventura, L.V.; Ciacci Zanella, J.R. Erradicação da doença de Aujeszky no estado de Santa Catarina. XII Congresso da Abraves, Fortaleza, 2005, p.127-128.

13. Morés, N.; Ciacci Zanella, J.R. Programa de erradicação da doença de Aujeszky no estado de Santa Catarina. Concórdia, SC: Embrapa Suínos e Aves, 2003. 50p. (Embrapa Suínos e Aves. Documentos, 81).

14. Piatti, R.M.; Ikuno, A.A.; Cunha, E.S.; Dambros, R.D.; Gregori, F.; Soares, R.M.; Cortez, A.; Richtzenhain, L.J. Characterization of Aujeszky's disease virus isolates from South and Southeast Brazil by RFLP analysis. Braz. J. Microbiol., 32, 144-146, 2001.

15. Rixon, F.J.; Ben-Porat, T. Structural evolution of the DNA of pseudorabies defective viral particles. Virology, 97, 151-163, 1979.

16. Sambrook, J.; Fritsch, E.F.; Maniatis, T. Molecular cloning: A Laboratory Manual, Cold Spring Harbor Laboratory Press, New York, USA, 1989.

17. van Oirschot, J.T.; Kaashoek, M.J.; Rijsewijk, F.A.M.; Stegeman, J.A. The use of marker vaccines in eradication of herpesviruses. $J$. Biotechnol., 44, 75-81, 1996.

18. Wheeler, J.G.; Osorio, F.A. Investigation of sites of pseudorabies virus latency, using polymerase chain reaction. Am. J. Vet. Res., 52(11), 1799-1803, 1991. 